International Journal of Current Advanced Research

ISSN: O: 2319-6475, ISSN: P: 2319 - 6505, Impact Factor: SJIF: 5.995

Available Online at www.journalijcar.org

Volume 6; Issue 4; April 2017; Page No. 3029-3030

DOI: http://dx.doi.org/10.24327/ijcar.2017.3030.0170

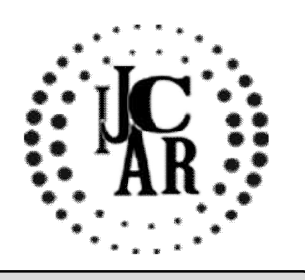

Research Article

\title{
ANTIBACTERIAL ACTIVITY OF PLECTRANTHUSAMBONICUS ON SELECTED ORAL MICROBES
}

Priadarsini T and Geetha R.V

Saveetha Dental College, 162, Poonamallee High Road, Chennai-77

\begin{tabular}{|c|c|}
\hline 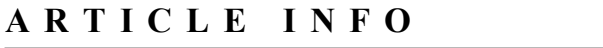 & A B S T R A C T \\
\hline Article History: & $\begin{array}{l}\text { Objective: The objective of this study was to find the efficiency of extract of Pletranthus } \\
\text { ambonicus when tested on selected oral microbes }\end{array}$ \\
\hline $\begin{array}{l}\text { Received } 11^{\text {th }} \text { January, } 2017 \\
\text { Received in revised form } 19^{\text {th }} \text { February, } 2017 \\
\text { Accepted } 22^{\text {nd }} \text { March, } 2017 \\
\text { Published online } 28^{\text {th }} \text { April, } 2017\end{array}$ & $\begin{array}{l}\text { Methods: The investigation was done by Agar well diffusion method. } \\
\text { Result: Plectranthus ambonicus has antibacterial activity against Streptococcus mutans } \\
\text { showing a zone of inhibition of } 27 \mathrm{~mm} \text {, which is the major initiator of dental caries. It also } \\
\text { has inhibitory effect against Enterococcus faecalis and Lactobacillus acidophilus. }\end{array}$ \\
\hline & $\begin{array}{l}\text { Conclusion: The extract Plectranthus ambonicus showed a significant antibacterial } \\
\text { activity. Detailed study on pharmacological activities such as anti inflammatory study }\end{array}$ \\
\hline $\begin{array}{l}\text { Plectranthus ambonicus, Indian bo } \\
\text { antibacterial, oral microbes, agar } \mathrm{u}\end{array}$ & $\begin{array}{l}\text { and others on this plant is needed for future health care product formulations like } \\
\text { mouthwashes and toothpastes. }\end{array}$ \\
\hline
\end{tabular}
method.

Copyright $₫ 2017$ Priadarsini T and Geetha R.V. This is an open access article distributed under the Creative Commons Attribution License, which permits unrestricted use, distribution, and reproduction in any medium, provided the original work is properly cited.

\section{INTRODUCTION}

Plant oils and extracts have been used for a wide variety of purposes for many thousands of years [1]. Natural products are a major source of new natural drugs and their use as an alternative medicine for treatment of various diseases has been increased in the last few decades.Oral diseases, including caries and periodontal disease, are especially of concern to public health, where they affect a large part of the population, leading dental professionals to seek alternatives for their control. Medicinal plants represent a rich source of anti bacterial agents which can be used to control oral diseases. Plectranthus ambonicus is one amongst them.Indian borage (Plectranthus ambonicus Benth), also known as country borage, is a medicinal plant used widely in Indian medicine. It is a succulent, aromatic, perennial herb belonging to the family Lamiaceae, and decoction of its leaves is used for several medicinal purposes (2). The leaf of Plectranthus ambonicushas many medicinal uses, especially for the treatment of common illnesses such as of cough, stomachache, headache, skin infection, asthma and urinary conditions (3). The plant extracts especially the volatile essential oils from the leaves have been reported to possess antioxidant, antibacterial, antimicrobial, anti-inflammatory and fungi-toxic activities (4) but due to the geographical region and variety, the activity and composition of essential oils may be vary.

*Corresponding author: Priadarsini T

Saveetha Dental College, 162, Poonamallee high road, Chennai-77
Therefore, it is important to access the local Plectranthus ambonicus to screen the potential biological activity especially antimicrobial properties and volatiles components of the plant. The objective of this work was to evaluate the antibacterial activity of the essential oil of Plectranthus ambonicus, a plant used by the local population for the treatment of diseases of the oral cavity against Streptococcus mutans, Enterococcus faecalis and Lactobacillus acidophilus.

\section{MATERIALS AND METHODS}

\section{Test microorganisms}

Bacterial strains used were Streptococcus mutans, Enterococcus faecalis and Lactobacillus acidophilus. The organisms were maintained in nutrient agar slope at $4^{\circ} \mathrm{C}$ in department of Microbiology, Saveetha Dental College. The crude extract ofPlectranthus ambonicuswas dissolved in distilled water in following concentrations $2.5 \mathrm{mg} / \mathrm{ml}, 5 \mathrm{mg} / \mathrm{ml}$ and $10 \mathrm{mg} / \mathrm{ml}$ so that $100 \mu \mathrm{l}$ delivers $250 \mu \mathrm{g} / \mathrm{ml}, 500 \mu \mathrm{g} / \mathrm{ml}$ and $1000 \mu \mathrm{g} / \mathrm{ml}$ respectively.

\section{Screening of antibacterial activity [Agar well diffusion technique]}

Broth culture of the bacterial strain compared to Mac Farland's standard ${ }^{[5,6]} 0.5$ was prepared. Lawn culture of the test organisms were made on the Muller Hinton agar [MHAHi media M1084] plates using sterile cotton swab and the plates were dried for 15 minutes. Wells measuring $4 \mathrm{~mm}$ depth were cut on the plate with sterile cork borer. $100 \mu l$ of the different concentrations of the extract were filled in the wells on the respective plates. The plates were incubated at $37^{\circ} \mathrm{C}$ 
overnight and the zone of inhibition of growth was measured in millimetres. All the tests were done in triplicate to minimise the test error.(7-11)

\section{RESULTS AND DISCUSSION}

The investigation on the antibacterial activity of Plectranthus ambonicus against Streptococcus mutans, Enterococcus faecalis and Lactobacillus acidophilusis tabulated in table 1 and fig 1

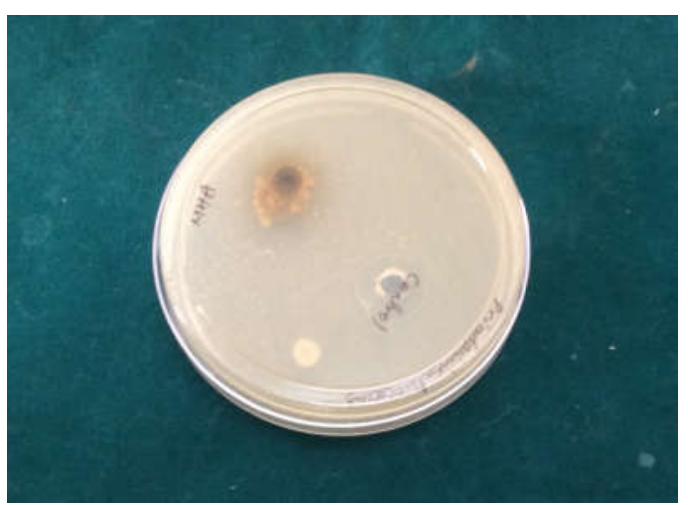

Fig 1 Zone of inhibition of Enterococcus faecalis

Table1 Zone of inhibition in mm diameter

\begin{tabular}{cccc}
\hline \multicolumn{4}{c}{ Zone of Inhibition In Mm Diameter } \\
\hline & E1 & E2 & E3 \\
Plectranthus & $20 \mathrm{~mm}$ & $25 \mathrm{~mm}$ & $21 \mathrm{~mm}$ \\
ambonicus & & $27 \mathrm{~mm}$ & $26 \mathrm{~mm}$ \\
\hline
\end{tabular}

E1 - Enterococcus faecalis; E2- Streptococcus mutans; E3Lactobacillus acidophilus

From the above results it is evident that Plectranthus ambonicus has antibacterial activity against Streptococcus mutans showing a zone of inhibition of $27 \mathrm{~mm}$, which is the major initiator of dental caries. It also has inhibitory effect against Enterococcus faecalis and Lactobacillus acidophilus. Medicinal plants are believed to be important source of new chemical substances with potential therapeutic effects. The secondary metabolites of plants were found to be source of various phytochemicals that could be directly used as intermediates for the production of new drugs. The use of herbs in dentistry should be based on evidence of effectiveness and safety. The present study has shown the antibacterial activity of Plectranthus ambonicus extract on the oral microbes tested. Anti-bacterial activities could be enhanced if active components are purified and adequate dosage determined for proper administration.

\section{CONCLUSION}

The extract Plectranthus ambonicus showed a significant antibacterial activity. Detailed study on pharmacological activities such as anti inflammatory study and others on this plant is needed for future health care product formulations like mouthwashes and toothpastes. The scope for drug development from this plant is endless and there is undoubtedly a call for further research into this area.

\section{Reference}

1. Jones, F.A. (1996) Herbs -useful plants. Their role in history and today. European Journal of Gastroenterology and Hepatology 8, 1227-1231.

2. Lukhoba CW, Simmonds MSJ, Paton AJ. Plectranthus: a review of ethnobotanical uses. $J$ Ethnopharmacol.2006; 103:124.

3. SitiFuziah, Y. (2012). Ulamandisekelilingkita. Arrisalah Product. Selangor

4. Bhatt, P. and Negi, P. S. (2012). Antioxidant and antibacterial activities in the leaf extracts of Indian borage (Plectranthusambionicus). Food and Nutrition Sciences 3: 146-152

5. Connie R.Mahon., George Manuselis., Saunder's Diagnostic Microbiology 2 edition Mosby page 229 257.

6. Vuorelaa P, Leinonenb M, Saikkuc P, Tammelaa P, Rauhad JP, Wennberge T, Vuorela H: Natural products in the process of finding new drug candidates. Curr Med Chem. 2004, 11: 1375-1389.

7. Shahroom.Netal ;invitro evaluation of anti bac act of clove bud oil on bacteria; Int. J. Pharm. Sci. Rev. Res., 36(2), January -February 2016; Article No. 11, Pages: 59-60

8. Lakshmi.T, Geetha R.V, Anitha Roy, "In vitro Evaluation of Antibacterial activity of Ethanolic and Aqueous leaf extracts of Sesbania grandiflora (Linn) against Clinical Pathogens", Int. J. Drug Dev.\& Res., July-Sep 2011, 3(3): 217-221

9. Geetha R. V et al /J. Pharm. Sci. \& Res. Vol.5(10), 2013, $207-209$

10. Thanish Ahamed S et al /J. Pharm. Sci. \& Res. Vol. 8(6), 2016, 491-492

11. Geetha et al. Asian J PharmClin Res, Vol 4, Suppl 2, 2011, 115-118

\section{How to cite this article:}

Priadarsini T and Geetha R.V (2017) ' Antibacterial Activity Of Plectranthusambonicus On Selected Oral Microbes', International Journal of Current Advanced Research, 06(04), pp.3029-3030.

DOI: http://dx.doi.org/10.24327/ijcar.2017.3030.0170 